\title{
Simental Irkı Bir Buzağıda Atresia Ani ve Rektoüretral Fistül Olgusu
}

\author{
Ali Said DURMUŞ ${ }^{1, a, *}$, Eren POLAT ${ }^{1, b}$ \\ ${ }^{1}$ Fırat Üniversitesi, Veteriner Fakültesi, Cerrahi Anabilim Dalı, Elazığ, Türkiye \\ aORCID: 0000-0003-4873-5690, bORCID: 0000-0002-3999-1310
}

Geliş Tarihi: 01.10.2019

Kabul Tarihi: 04.12.2019

Özet: Bu olgu sunumunda prepisyumundan dışkı geldiği ve anüsten defekasyon yapamadığı şikâyetiyle kliniğimize getirilen üç günlük simental ırkı erkek bir buzağının operatif tedavisinin tanımlanması amaçlandı. Yapılan klinik ve radyografik muayeneler sonucunda atresia ani ve rektoüretral fistül tanısı konuldu. Premedikasyon ve lokal anestezi uygulamasını takiben deri ve derialtı bağ dokuları ensize edilerek rektuma ulaşıldı. Çevre dokulardan küt diseksiyon ile ayrılan rektum operasyon yarasından dışarı çekildi. Rektumun kapalı olan uç kısmı açıldıktan sonra üretraya açılan fistül deliği bulunan rektum parçası ekstirpe edildi. Ekstirpasyon işlemi sonrası rektum anal bölgedeki derialtı bağ doku ve deriye dikilerek anüs oluşturuldu. Postoperatif olarak 7 gün boyunca parenteral antibiyotik uygulaması ve ılık antiseptikli sularla yara bakımı gerçekleştirildi. Deri dikişleri 10 gün sonra alındı. Operasyon sonrası 6 ay boyunca hasta sahibi ile yapılan görüşmelerde olguda herhangi bir komplikasyon bulunmadığı tespit edildi.

Anahtar Kelimeler: Atresia ani, Rektoüretral fistül, Buzağı.

\section{A Case of Atresia Ani and Rectourethral Fistula in a Simmental Calf}

\begin{abstract}
In this case report, we aimed to describe the operative treatment of a three-day simmental breed male calf who was brought to our clinic with the complaint of stool coming from the preputium and not defecation from the anus. As a result of clinical and radiographic examinations, atresia ani and rectourethral fistula was diagnosed. Following premedication and local anesthesia, the skin and subcutaneous connective tissues were incised and the rectum was reached. The rectum, which was separated from the surrounding tissues by blunt dissection, was pulled out of the operation wound. After the closed end of the rectum was opened, the rectum part with a fistula hole opening into the urethra was extirpated. After the extirpation procedure, anus was created by suturing to the subcutaneous connective tissue and skin in the rectum anal region. Postoperative parenteral antibiotic administration and wound care with antiseptic warm water were performed for 7 days. Skin sutures were removed 10 days later. In the interviews with the owner for 6 months postoperatively, it was detected that the calf has any complication.

Keywords: Atresia ani, Rectourethral fistula, Calf.
\end{abstract}

\section{Giriş}

Sindirim sistemi ve ürogenital sistem anomalileri, evcil hayvanlarda fazlaca karşılaşılan konjenital anomalilerdendir. Atresia ani, kolon agenezisi ve rektovaginal fistül yaygın olarak karşılaşılan doğmasal anomaliler iken, rektoüretral fistül gibi anomalilerle nadiren karşılaşılmaktadır (Chauhan ve ark., 2011; Özaydın ve ark., 2006; Varol ve ark., 2018; Yayla ve ark., 2016). Konjenital anomalilerin nedenleri tam olarak bilinmemesine rağmen, mutasyon ve kromozomal defektler gibi genetik faktörlere, intrauterin dönemde oluşan viral ve bakteriyel hastalıklara, gebelik sırasında oluşan yem kaynaklı intoksikasyonlara ve gebeliğin erken döneminde yapılan rektal muayenelere bağlı olarak gelişebileceği tahmin edilmektedir (Bademkıran ve ark., 2009; Chauhan ve ark., 2011; Han ve ark., 2005; Hussein, 2010; Kılıç ve ark., 2005; Kılıç ve ark., 2006; Özaydın ve ark., 2006; Varol ve ark., 2018; Yayla ve ark., 2016; Yayla ve ark., 2017). Bu olguda Simental ırkı bir buzağıda karşılaşılan atresia ani ve rektoüretral fistül olgusunun tanımlanması, teşhisi, operatif yolla tedavisi ve postoperatif sonuçlarının değerlendirilmesi amaçlanmıştır.

\section{Olgu Tanımı}

Olguyu normal yollarla defekasyon yapamama ve doğduğu günden itibaren prepitiumunun ucundan dışkı gelmesi şikâyeti ile getirilen üç günlük simental ırkı erkek bir buzağı oluşturdu. Alınan anemnez doğrultusunda buzağıda iki gündür iştahsızlık bulunduğu ve karın bölgesinde şişlik olduğu öğrenildi. Yapılan klinik muayenelerde buzağıda anüsün kapalı olduğu, abdomende şişlik ve şişliğe bağıı sancı oluştuğu saptandı. Ayrıca dışkının prepisyumun ucundan dışarı aktığı gözlendi (Şekil 1A). Yapılan radyografik muayenede sindirim sisteminin yoğun gaz ve dışkıyla dolu olduğu tespit edilen (Şekil 1B) buzağıya atresia ani ve rektoüretral fistül tanısı konuldu. 

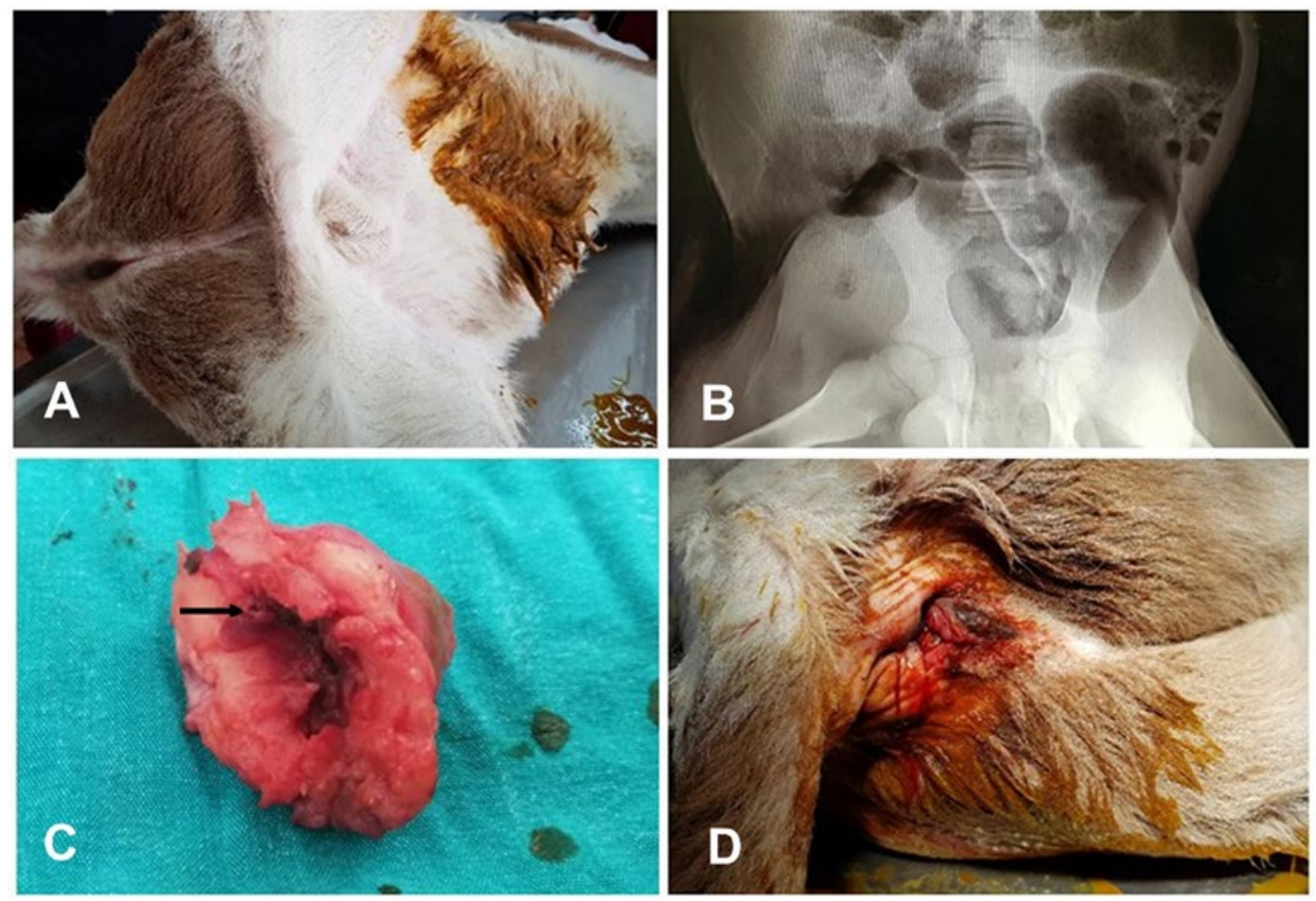

Şekil 1. A: Atresia ani ve rektoüretral fistülden kaynaklı prepisyumdan dışkı gelişi. B: Buzağının preoperatif abdominal radyografisi. C: Rektumun ekstirpe edilen ucu ve fistül deliği (ok). D: Postoperatif görünüm.

Operasyon hazırlıkları yapılan buzağıya anestezi için $0.1 \mathrm{mg} / \mathrm{kg}$ dozunda intramuskuler olarak ksilazin hidroklorür (Rompun, Bayer, 23.32 $\mathrm{mg} / \mathrm{ml}$ ) verildikten 10 dakika sonra $4 \mathrm{mg} / \mathrm{kg}$ dozunda intramuskuler ketamin hidroklorür (Ketasol \%10, interhas, $100 \mathrm{mg} / \mathrm{ml}$ ) verildi. Operasyon yapılacak olan anal bölgeye ise $10 \mathrm{ml}$ Lidokain hidroklorür (L-Anestine, Alke, $20 \mathrm{mg} / \mathrm{ml}$ ) ile lokal infiltrasyon anestezisi yapıldı. Anesteziyi takiben anal bölge derisi üzerine artı " + " şeklinde deri ensizyonu yapıldı. Deri altı bağ dokularının küt diseksiyonu sonrasında rektuma ulaşıldı. Pensler yardımıyla dikkatlice dışarı doğru çekilen rektumun kapalı olan ucu bir makas yardımıyla açılarak içerisinde birikmiş olan bol miktardaki mekonyumun boşaltılması sağlandı. Mekonyumun tamamen boşaltılması tamamlandıktan sonra rektum ventralindeki fistül deliği tespit edildi. Fistül deliğinin rektumun uç kısmına yakın olması nedeniyle fistül deliğini içerisine alacak şekilde rektumun kapalı olan uç kısmı ekstirpe edilip (Şekil 1C), rektumun uç kısmı anal bölgedeki derialtı bağ doku ve deriye 2/0 numara ipek iplikle dikilerek tespit edildi (Şekil 1D).

Postoperatif olarak 7 gün boyunca 1 $\mathrm{mg} / \mathrm{kg} /$ gün dozunda seftiofur hidroklorid (Eficure, Hipra $50 \mathrm{mg} / \mathrm{ml}$ ) intramuskuler olarak uygulandı.

Anal bölgedeki yara 10 gün boyunca $\% 0.1^{\prime}$ lik povidone iodee' ile silindi. Postoperatif 10. gün buzağı kontrol edilerek dikişleri alındı. Altı ay boyunca hasta sahibi ile yapılan görüşmelerde buzağının normal yollardan defekasyon yaptığı ve postoperatif herhangi bir komplikasyonu bulunmadığı tespit edildi.

\section{Tartışma ve Sonuç}

Atresia ani, özellikle buzağılarda olmak üzere bütün evcil hayvanlarda en çok karşılaşılan konjenital anomalilerden birisidir. Rektoüretral fistül ise nadiren karşılaşılan konjenital anomalilerdendir (Chauhan ve ark., 2011; Özaydın ve ark., 2006; Varol ve ark., 2018; Yayla ve ark., 2016). Bu olgu sunumunda simental ırkı bir buzağıda karşılaşılan atresia ani ve rektoüretral fistül olgusunun tanımı, teşhisi, operatif tedavisi ve postoperatif sonuçları konu edilmiştir.

Konjenital anomalilerin nedenleri tam olarak bilinmemekle birlikte kromozomal defektler ve mutasyonların sebep olduğu genetik faktörler, gebelik döneminde karşılaşılan bakteriyel ve viral hastalıklar ile yeme bağlı intoksikasyonlardan kaynaklı olabileceği düşünülmektedir. Yine gebeliğin erken dönemlerinde sık olarak yapılan rektal muayenelerin de konjenital anomalilere sebep olabileceği bildirilmiştir (Bademkıran ve ark., 2009; Chauhan ve ark., 2011; Han ve ark., 2005; Hussein 2010; Kılıç ve ark., 2005; Kılıç ve ark., 2006; Özaydın ve ark., 2006; Varol ve ark., 2018; Yayla ve ark., 2016; Yayla ve ark.,2017).

Bu olguda hasta sahibinden alınan anamnezde, gebeliğin erken döneminde sık olarak rektal muayene yapıldığı bilgisinin alınması anomalinin 
sebebinin bu durumdan kaynaklanabileceğini düşündürmektedir.

Anüsün açık fakat dar olarak şekillendiği ve rektumun normal olduğu (tip 1), anüsün ince bir membranla kapalı durumda bulunması ve rektumun kör bir kese şeklinde hemen anüsün önünde yer aldığı (tip 2), anüsün oluşmadığı ve rektumun kör bir kese şeklinde anüsün hemen önünde yer aldığı (tip 3), rektumun terminal bölümü ile anüsün normal olduğu ve pelvis kanalında rektumda atresianın bulunduğu (tip 4) 4 tip atresia bulunmaktadır (Chauhan ve ark., 2011; Durmuş ve ark., 2011; Ghanem ve ark., 2005; Purohit ve ark., 2006; Varol ve ark., 2018). Varol ve ark. (2018), bir Anadolu mandasının buzağısında, Durmuş ve Çınar (2011) ise simental ırkı dişi bir buzağıda Tip 2 atresia ani olgusu bildirirlerken; Chauhan ve ark. (2011), iki günlük bir buzağıda Tip 1 atresia ani olgusu bildirmişlerdir. Sunulan bu olguda ise, anüs tamamen oluşmadığı ve rektumun kör bir kese şeklinde anüsün önünde (Tip 3) olduğu tespit edildi.

Rektoüretral fistül, nadiren karşımıza çıkan ve genellikle başka diğer doğmasal anomalilerle beraber görülen konjenital bir defekttir. Yayla ve ark. (2016), bir aylık simental ırkı bir buzağıda rektoüretral fistül ile birlikte şekillenen üretral dilatasyon ve segmental üretral agenezi olgusunu bildirmişlerdir. Özaydın ve ark. (2006), bir günlük Montafon ırkı erkek bir buzağıda rektoüretral fistül ile beraber atresia ani ve polimelia olgusunu bildirmişlerdir. Bu olguda da rektoüretral fistül ile atresia ani birlikte tespit edilmiştir.

Yayla ve ark. (2017), tespit ettikleri rektoüretral fistül olgusunda, klinik muayene sırasında buzağının perianal bölgesi ile skrotal bölgesi arasında şişlik oluştuğunu ve dışkıyla idrarın bu bölgede biriktiğini tespit etmişlerdir. Bu olguda ise, perianal bölgenin klinik muayenesinde herhangi bir şişlik olmadığı fakat prepisyumun ucundan dışkı ile bulaşık bir akıntı olduğu tespit edildi.

Sunulan bu olguda atresia ani'yi tedavi etmek amacıyla bilinen operatif yöntem kullanıldı ve alınan olumlu sonuçların daha önce bildirilen raporlarla (Durmuş ve ark., 2003; Durmuş ve ark., 2011; Suthar ve ark., 2010; Varol ve ark., 2018) uyumluluk gösterdiği belirlendi. Rektoüretral fistülün tedavisinde çoğunlukla rektum üzerinde bulunan fistül deliği onarılırken; bu olguda rektumun ventralinde bulunan fistül deliğini içeren rektum kısmı ekstirpe edilip fistül ağzı kapatıldıktan sonra, rektum anal bölgedeki derialtı bağ dokusuyla birlikte deriye usulüne uygun olarak tespit edildi ve olumlu sonuç alındı.

Sonuç olarak, rektoüretral fistül ve Tip 3 atresia ani olgusunun birlikte oluşabileceği, bu tip olgularda yapılacak olan operatif tedavi ile hayvanının yaşamını normal olarak devam ettirebileceği kanısına varıldı.

\section{Kaynaklar}

Bademkıran S, icçen H, Kurt D, 2009: Congenital rectovaginal fistula with atresia ani in a heifer. YYÜ Vet Fak Derg, 20(1), 61-64.

Chauhan PM, Parmar VR, Patel TP, Thakor KB, Parikh SS, 2011: Atresia ani: A congenital defect and its successful management in non-descript calf. IJAVMS, 5(6), 520-522.

Durmuş AS, Han MC, 2003: Bir buzağıda rastlanan atresia ani ve perosomus elumbus olgusu. Doğu Anadolu Bölgesi Araştırmaları Dergisi, 2(1), 54-56.

Durmuş AS, Çınar HN, 2011: Bir buzağıda rastlanılan rektovaginal fistül, atresia ani ve perosomus elumbus olgusu. FÜ Sağ Bil Vet Derg, 25(1), 43-47.

Ghanem ME, Yoshida C, Nishibori M, Nakao T, Yamashiro $H, 2005$ : A case of freemartin with atresia recti an ani in Japanese black calf. Anim Reprod Sci, 85(3-4), 193-199.

Han MC, Durmuş AS, 2005: Buzağılarda bazı konjenital anomali olguları. Doğu Anadolu Bölgesi Araştırmaları Dergisi, 3(2), 175-177.

Hussein RMN, 2010: Congenital anomalies in cattle and buffalo within mudaina city in Basrah province between period 2007-2009. Kufa J Vet Sci, 1(1), 207218.

Kılıç E, Öztürk S, Aksoy O, Özaydın I, Özba B, Dağ-Erginsoy S, 2005: Preputial aplasia, urethral diverticulum and distal urethral atresia in kids. Kafkas Univ Vet Fak Derg, 11(1), 73-76.

Kılıç E, Özaydın I, Aksoy O, Yayla S, Sözmen M, 2006: Multiple urogenital system anomalies in three calves. Kafkas Üniv Vet Fak Derg, 12(2), 193-197.

Özaydın I, Kılıç E, Aksoy Ö, Cihan M, Güngör E, 2006: Bir buzağıda üçlü malformasyon: atrezi ani, rektouretral fistül ve pygomelia. Kafkas Üniv Vet Fak Derg, 12(2), 189-191.

Purohit S, Gahlot TK, Parashar MC, Rathore VS, 2006: Surgical management of rectovaginal fistula with atresia ani in a calf. The Indian Cow, 2(7), 39-40.

Suthar DN, Chaudhary SR, Patel PB, 2010: Surgical management of atresia ani in a cow calf. Vet World, 3(8), 380-381.

Varol K, Atalan G, Günes V, Alpman U, Yönez MK, 2018: A case of atresia ani in an anatolian water buffalo calf. Erciyes Üniv Vet Fak Derg, 15(3), 271-275.

Yayla S, Kılıç E, Baran V, Özen H, 2016: A case of congenital rectourethral fistula, urethral dilatation and segmental urethral agenesis encountered in a calf. Harran Üniv Vet Fak Derg, 5(1), 70-73.

Yayla S, Kılıç E, Özen H, Baran V, Aydın U, Karakurt E, 2017: Simental ırkı bir buzağıda çoklu ürogenital sistem anomalisi. Harran Üniv Vet Fak Derg, 6(1), 95-98.

${ }^{*}$ Yazışma Adresi: Ali Said DURMUŞ

Fırat Üniversitesi, Veteriner Fakültesi, Cerrahi Anabilim

Dalı, Elazı̆̆, Türkiye.

e-mail: asdurmus@firat.edu.tr 